\title{
Dioscorea cumingii Prain \& Burkill - a new distributional record for Tripura in North-east India
}

\author{
Dipti Das ${ }^{1}$, Somnath Kar ${ }^{2}$ and B. K. Datta ${ }^{3}$ \\ ${ }^{1}$ Communicating author: Department of Botany, Netaji Subhash Mahavidyalaya, Udaipur 799114, Tripura, \\ India.E-mail:diptiagt@rediffmail.com \\ ${ }^{2}$ Department of Botany Holy Cross College, Lembucherra 799210, Tripura, India \\ ${ }^{3}$ Plant Taxonomy and Biodiversity Laboratory, Department of Botany, Tripura University, \\ Suryamaninagar-799022, Tripura, India
}

[Received 01.12.2019; Revised 22.12.2019; Accepted 27.2019; Published 31.12.2019]

\begin{abstract}
The present paper deals with the new distributional record of Dioscorea cumingii for the North-east Indian state Tripura. A brief description and photographs provided to identify it easily in the field.
\end{abstract}

Key words: Dioscoreaceae, Dioscorea cumingii, New record, Tripura

\section{INTRODUCTION}

The genus Dioscorea L. (Dioscoreaceae) comprises of about 600 species distributed all over the world, especially in tropical and sub-tropical regions (Trimanto \& Hapsari 2015). Out of these, about 91 species are reported from North-eastern part of India (Ummalyma et al. 2018), of which 30 species from Arunachal Pradesh (Saikia et al. 2011), 19 species from Assam (Goswami et al. 2013), 16 species from Meghalaya (Sheikh et al. 2009), 12 species from Sikkim (Pradhan et al. 2015;), 10 species from Tripura (Paul et al., 2017) and 4 species from Manipur (Kumar et al. 2017). Most of the species are distributed in the tropical and subtropical regions of the world. The North East India forms part of two IUCN declared Biodiversity Hotspots [Himalaya and Indo-Burma] is particularly rich in tropical root and tuber crops (Goswami et al. 2013). Species of Dioscorea are in luxuriant growth in wild habitat in this region. During one ongoing study, mainly addressed to explore the ethnomedicinal uses of Dioscorea in North East India, we recorded a plant that is now identified as Dioscorea cumingii from West Tripura. Earlier, Deb (1983) recorded only 6 species and two varieties of Dioscorea in his Flora of Tripura state. Majumder et al. (2009) reported D. hispida Dennsted from Tripura and Paul et al. (2017) mentioned the occurrence of 10 species of Dioscorea from Tripura. Now, with the addition of Dioscorea cumingii, the number of species of Dioscorea for state is increased to 11.

\section{Taxonomic treatment}

Dioscorea cumingii Prain \& Burkill, J. As. Soc. Beng. new ser. 4: 449. 1908; Ann. Roy Bot. Gard. Calc. 14: 182.1936, pl. 73. R.Knuth, Pfl. R. 87: 148. 1924. D inaequitifolia Elmer ex Prain \& Burkill, J. As. Soc. Beng. N.S. 10: 24.1914; R. Knuth op. cit. 146; Prain \& Burkill, Ann. Roy Bot. Gard. Calc. 14: 181. 1936. D. polyphylla, R. Knuth, Pfl. R. 87: 148. 1924; Prain \& Burkill, Ann. Roy Bot. Gard. Calc. 14:184. 1936. D. echinata R. Knuth, Pfl. R. 87: 148. 

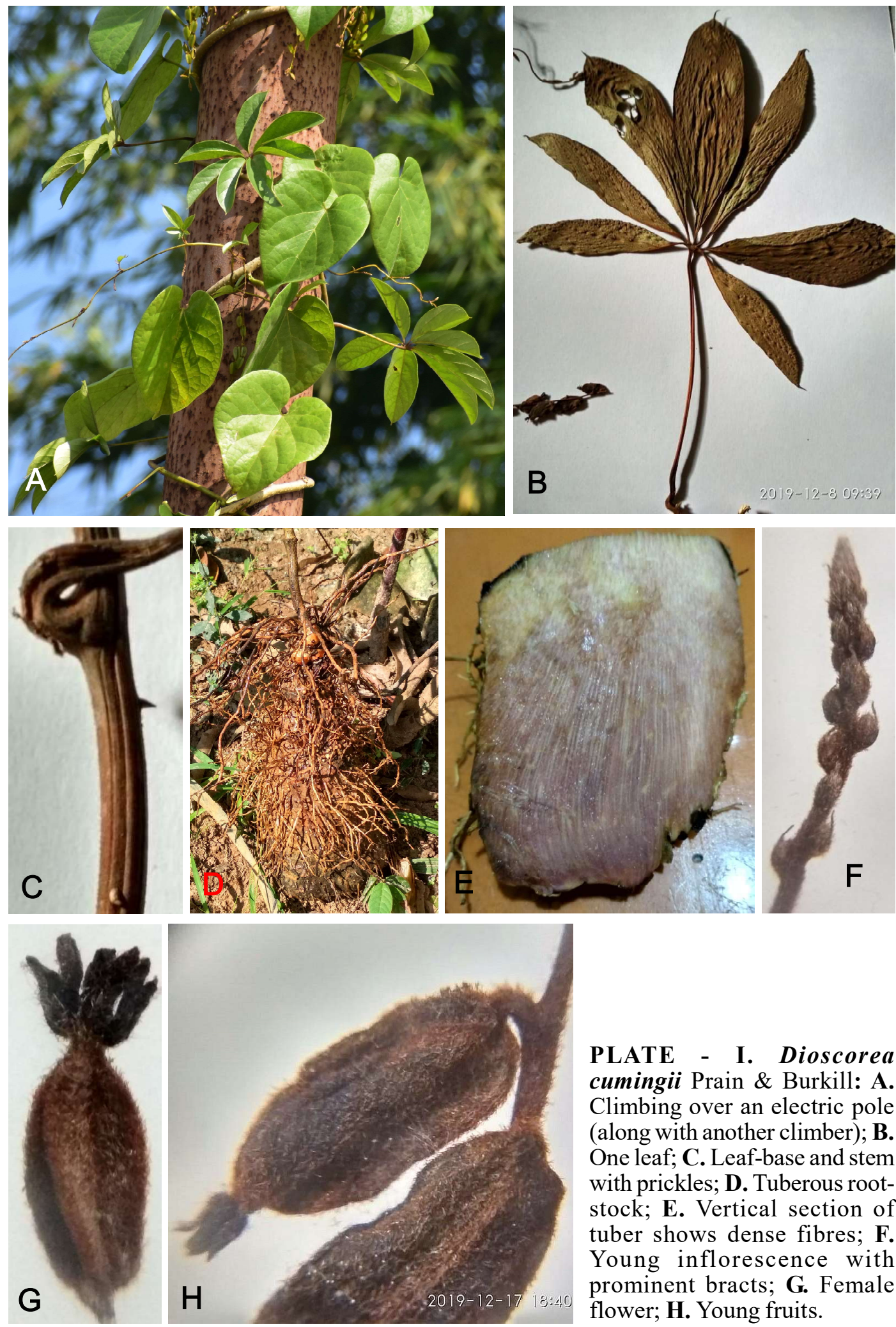

PLATE - I. Dioscorea cumingii Prain \& Burkill: A. Climbing over an electric pole (along with another climber); B. One leaf; C. Leaf-base and stem with prickles; D. Tuberous rootstock; E. Vertical section of tuber shows dense fibres; F. Young inflorescence with prominent bracts; G. Female flower; H. Young fruits. 
Climbing herb with annual arial shoot; root tuber fibrous with profuse roots. Stem twining to the left, prickly pubescent, yellowish-green. Leaves alternate, palmate-compound; petiole, $7-14 \mathrm{~cm}$ long, channelled above, pulvinus oblong; leaflets 5-7, 7-14 $\times 2-4.9 \mathrm{~cm}$, entire, rounded-acute, with $4-5 \mathrm{~mm}$ long acumen, base gradually cuneate, hairy, green. Racemes axillary, $15-22 \mathrm{~cm}$ long, pendulous; female racemes $1-2$ per axil, bracts small, subulate, tepal 6 , pubescent, $2-2.5 \mathrm{~mm}$, epigynous, ovary 3-winged, puberulent. Capsule 3-winged, oblong; seeds develope near tip of the chamber inside.

Exsiccatae: Tripura, Sekerkote, West Tripura, Das et al., TUH-2739, Dated 12.11.2019

Flowering: August - September

Fruiting: October - January

Global Distribution: Native of Taiwan and Philippines

Indian Distribution: Assam, Tripura

Uses: Lower part of tuber used as vegetable by local tribal people.

\section{Acknowledgements}

The authors are thankful to Tripura University for providing research facilities.

\section{LITERATURE CITED}

Deb, D.B. 1983. The Flora of Tripura state, Vol. 2. Today \& Tomorrows' Printers and Publishers, New Delhi. Pp. 417 - 422.

Goswami, N.; Borthakur, S.K. \& Hore, D.K. 2013. The genus Dioscorea Linnaeus [Dioscoreaceae] in Assam, India. Pleione 7(1): 73 - 83.

Kumar, S.; Das, G.; Shin, H.S. \& Patra, J.K. 2017. Dioscorea spp. (A Wild Edible Tuber): A Study on Its Ethno-pharmacological Potential and Traditional Use by the Local People of Similipal Biosphere Reserve, India. Fronti. Pharmac. 8: 1 - 17.

Majumder, K.; Saikia, B. \& Datta, B.K. 2009. A new recorded for Tripura, India (Dioscorea hispida Dennst.). Pleione. 3(2): 224 - 226.

Paul, C.; Debnath, A.; Chanda, R. \& Debnath, B. 2017. Taxonomical note, new distributional record and traditional use for Dioscorea wallichii Hook. f. (Dioscoreaceae) of Tripura North-East India. Ann. Pl. Sci. 6 (12): 1868 - 1871.

Pradhan, A.; Chettri, A. \& Gurung, S. 2015. Diversity and Distribution of Genus Dioscorea in Sikkim Himalaya, India: an application of DIVA-GIS. Intn. J. Env. Biodiv. 6 (3): 29 - 31.

Saikia, B.; Rawat, J.S.; Huitag \& Das, A. 2011. An investigation on the taxonomy and ecology of the genus Dioscorea in Arunachal Pradesh, India. J. Frontl. Res. 1: 44 - 53.

Trimanto, T. \& Hapsari, L. 2015. Diversity and utilization of Dioscorea spp. tuber as alternative food source in Nganjuk Regency, East Java. AGRIVITA, J. Agr. Sci.. 37(2): 97 - 107.

Ummalyma, S.B.; Devi, R.S. \& Kumar, S. 2018. Dioscorea hispida Dennst. (Dioscoreaceae) : a new addition to the state flora of Manipur, India. Pleione 12(1): $147-149$. 